ORNL/TM-13423

Dist. Category UC-523

\title{
IMPACT OF CONVERSION TO MIXED-OXIDE FUELS ON REACTOR STRUCTURAL COMPONENTS
}

\author{
G. T. Yahr
}

Date Published: April 1997

Prepared by

OAK RIDGE NATIONAL LABORATORY

Oak Ridge, Tennessee 37831 managed by

LOCKHEED MARTIN ENERGY RESEARCH CORP.

for the

U.S. DEPARTMENT OF ENERGY

under contract DE-AC05-96OR22464 


\section{Page Intentionally Blank}




\section{DISCLAIMER}

This report was prepared as an account of work sponsored by an agency of the United States Government. Neither the United States Government nor any agency thereof, nor any of their employees, makes any warranty, express or implied, or assumes any legal liability or responsibility for the accuracy, completeness, or usefulness of any information, apparatus, product, or process disclosed, or represents that its use would not infringe privately owned rights. Reference herein to any specific commercial product, process, or service by trade name, trademark, manufacturer, or otherwise does not necessarily constitute or imply its endorsement, recommendation, or favoring by the United States Government or any agency thereof. The views and opinions of authors expressed herein do not necessarily state or reflect those of the United States Government or any agency thereof. 


\section{DISCLAIMER}

Portions of this document may be illegible electronic image products. Images are produced from the best available original document. 


\section{CONTENTS}

ACRONYMS

PREFACE.

ABSTRACT

1

1. INTRODUCTION

1

2. RADIATION EFFECTS IN METALS .

2

3. COMPONENTS THAT MAY BE CHALLENGED BY A CHANGE TO MOX FUEL....................

3.1 REACTOR VESSEL ......................................................................................................

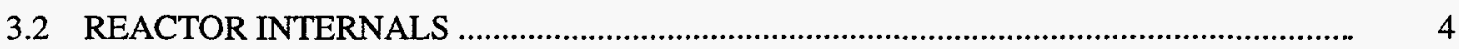

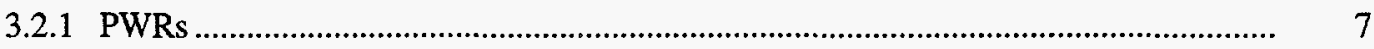

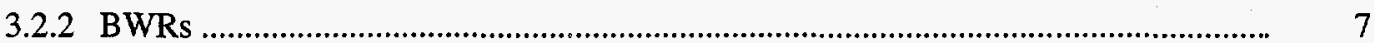

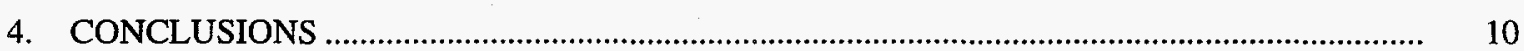

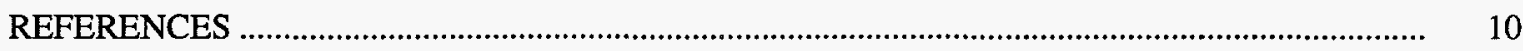

ATTACHMENT: A UTILITY'S EXPERIENCE: LICENSING \& USE OF MOX FUEL .................... 13 
Page Intentionally Blank 


\section{ACRONYMS}

$\begin{array}{ll}\text { BWR } & \text { boiling-water reactor } \\ \text { CRDM } & \text { control rod drive mechanism } \\ \text { DOE } & \begin{array}{l}\text { Department of Energy } \\ \text { displacements per atom }\end{array} \\ \text { dpa } & \text { Evaluated Nuclear Data File/File B, Version 5 } \\ \text { ENDF/B-V } & \text { High Flux Isotope Reactor } \\ \text { HFIR } & \text { irradiation assisted stress corrosion cracking } \\ \text { IASCC } & \text { intergranular stress corrosion cracking } \\ \text { IGSCC } & \text { light-water reactor } \\ \text { LWR } & \text { mixed oxide } \\ \text { MOX } & \text { materials test reactor } \\ \text { MTR } & \text { nil ductility transition temperature } \\ \text { NDTT } & \text { Oak Ridge Reactor } \\ \text { ORR } & \text { pressurized-water reactor } \\ \text { PWR } & \text { stress corrosion cracking }\end{array}$


Page Intentionally Blank 


\section{PREFACE}

This document is one in a series of topical reports written in support of the U.S. Department of Energy's (DOE's) Program Acquisition Strategy for Obtaining Mixed-Oxide Fuel Fabrication and Reactor Irradiation Services (PAS) [formerly Procurement Implementation Plan for Acquisition of Mixed-Oxide Fuel Fabrication Services and Reactor Irradiation Services (PIP)]. This series of topical reports is intended to increase access to available information for parties interested in responding to the PAS and the subsequent request for proposal. These topical reports address subjects relevant to DOE's strategy concerning disposition of surplus plutonium by irradiating mixed-oxide (MOX) fuel in existing, domestic commercial reactors. This report addresses possible structural integrity issues related to converting light-water reactors from low-enriched uranium fuel to MOX fuel. 


\title{
IMPACT OF CONVERSION TO MIXED-OXIDE FUELS ON REACTOR STRUCTURAL COMPONENTS
}

\author{
G. T. Yahr
}

\begin{abstract}
The use of mixed-oxide (MOX) fuel to replace conventional uranium fuel in commercial light-water power reactors will result in an increase in the neutron flux. The impact of the higher flux on the structural integrity of reactor structural components must be evaluated. This report briefly reviews the effects of radiation on the mechanical properties of metals. Aging degradation studies and reactor operating experience provide a basis for determining the areas where conversion to MOX fuel has the potential to impact the structural integrity of reactor components.
\end{abstract}

\section{INTRODUCTION}

Using plutonium as fuel in commercial power reactors is a way to dispose of the material formerly used in nuclear weapons. It is important that the structural integrity of the reactors not be compromised by the use of weapons-grade MOX fuels. Use of MOX fuels will result in an increase in the neutron flux and heating rates. ${ }^{1}$ The fission spectra for ${ }^{235} \mathrm{U}$ and ${ }^{239} \mathrm{Pu}$ and the neutrons per fission for each are shown in Fig. 1 for equal power densities. Because each ${ }^{239} \mathrm{Pu}$ fission produces an average of $19 \%$ more neutrons than a ${ }^{235} \mathrm{U}$ fission and because of the slightly higher energy neutrons produced by ${ }^{239} \mathrm{Pu}$ fission, a MOX core could result in up to $20 \%$ higher fast flux. A combination of MOX fuel and conventional fuel would result in a somewhat smaller increase in the fast flux.

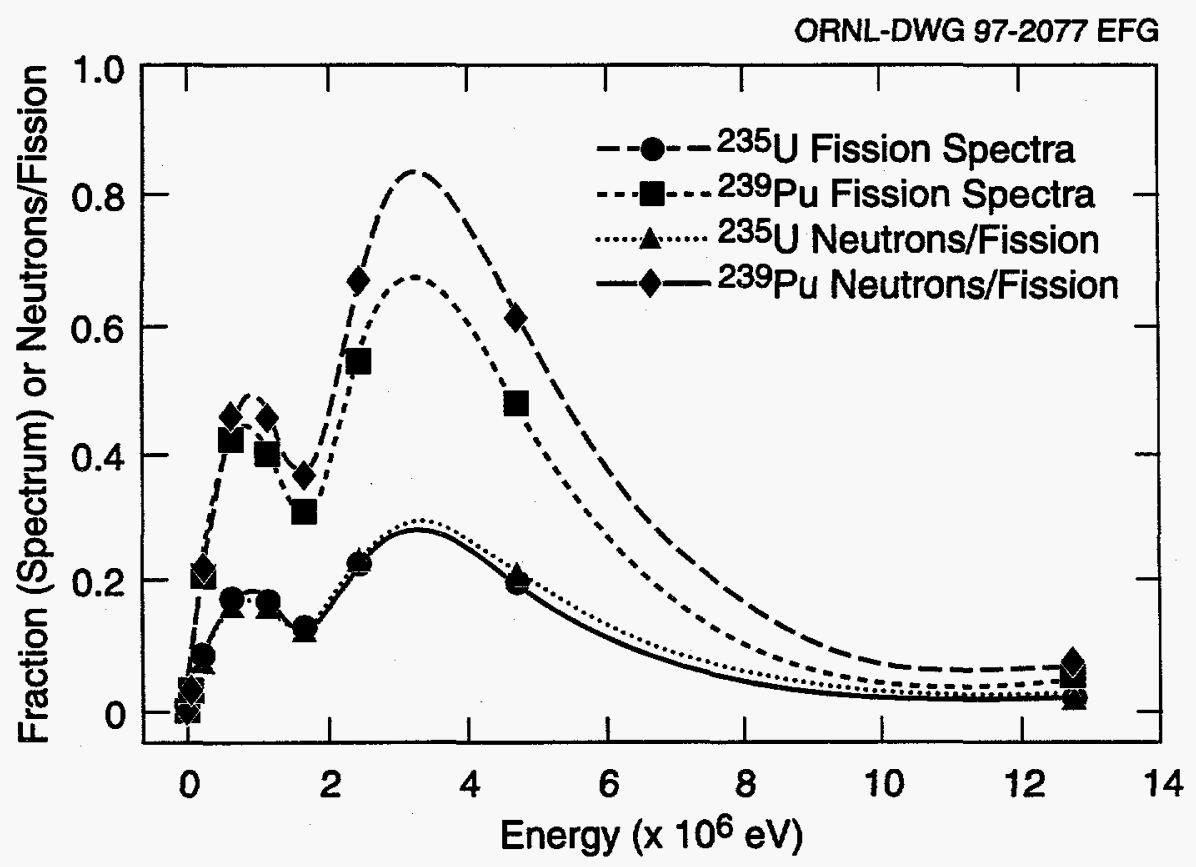

Fig. 1. Plutonium systems showing higher fast flux than $235 \mathrm{U}$ at equal power densities. 
Because nuclear radiation changes the properties of metals, it is important to make sure that the higher neutron flux associated with the use of MOX fuel will not cause changes that will compromise the structural integrity of the reactors in which it is used. The effects of neutron radiation on the properties of structural metals is discussed in Sect. 2.

Although the only reference to the impact of conversion to MOX fuel on reactor structural components found during this study was a note in a paper by J. Van $V_{y v e}^{2}$ that "the fast fluence on the pressure vessel is not increased with the MOX fuel core management," it should not be assumed that adverse structural aspects will not occur for the U.S. reactors (Ref. 2 is an attachment to this report). Detailed analysis is recommended to ensure that the structural effects are correctly anticipated. Consideration of recent studies of pressure vessel embrittlement ${ }^{3-8}$ and reactor internals aging degradation in commercial power reactors ${ }^{9-15}$ is recommended as the best way to identify the most likely areas to be impacted by conversion to MOX fuels. This work is discussed in Sect. 3.

\section{RADIATION EFFECTS IN METALS}

Radiation damage is primarily a result of displacement of atoms in the structural metals being knocked out of their location in the crystal lattice by collision with fast neutrons. ${ }^{16-22}$ There are other mechanisms that cause displacement of atoms. For example, one of the isotopes of nickel has a high cross section for thermal neutrons that ultimately results in $340-\mathrm{keV}$ iron atoms and $4.7-\mathrm{MeV}$ alpha particles that are just as damaging as extremely fast neutrons. ${ }^{17,19}$

Much of the data on radiation effects are given in terms of the total neutron fluence for neutrons with an energy level above $1 \mathrm{MeV}$ or above some other energy level. A more refined way of presenting radiation effects data is in terms of the number of displacements per atom (dpa), which is an estimate of how many times each atom is moved from its lattice position.

The displacement of atoms in the crystal lattice can induce swelling in metals and can increase the creep and stress relaxation rate. ${ }^{23}$ This can cause distortion, including bowing of fuel and control rods when the neutron fluence varies across the diameter. It may also reduce the preload in bolts and springs. Irradiation enhances stress corrosion cracking in some metals, especially austenitic stainless steels. ${ }^{24-28}$

Tensile strength is generally increased by irradiation, but ductility and fracture toughness are generally decreased. There is a transition temperature below which the toughness of ferritic steels decreases markedly. The effect of temperature on the fracture toughness of ferritic pressure vessel steels ${ }^{29}$ is shown in Fig. 2. The transition temperature is raised by irradiation. There is also some evidence that the toughness

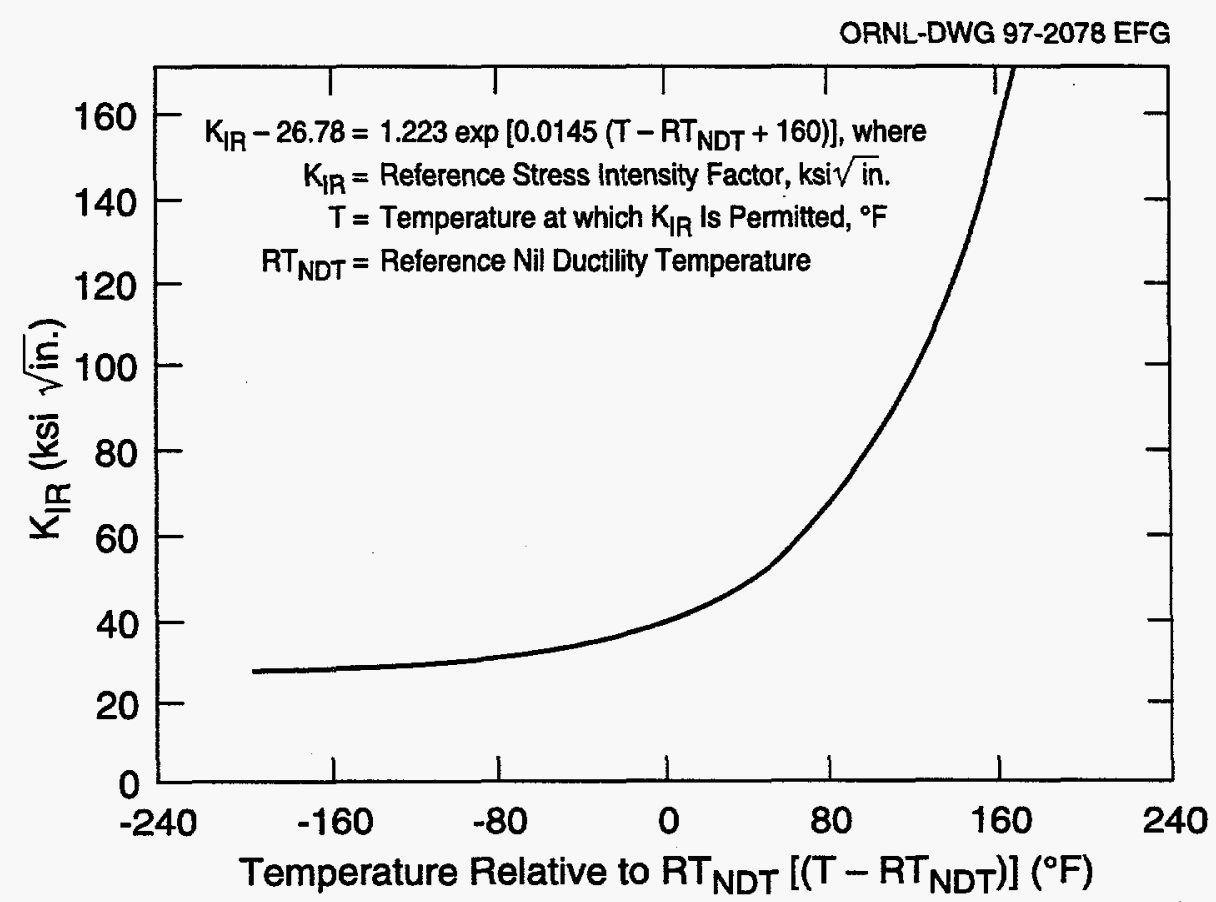

Fig. 2. Effect of temperature on fracture toughness of pressure vessel steel. 
below the transition temperature is further decreased by irradiation. Other metals such as zircaloy and austenitic steels do not undergo a ductile-brittle transition as the temperature decreases. However, their fracture toughness is decreased by irradiation, as shown in Fig. 3 for 304 and 316 stainless steel. ${ }^{30}$

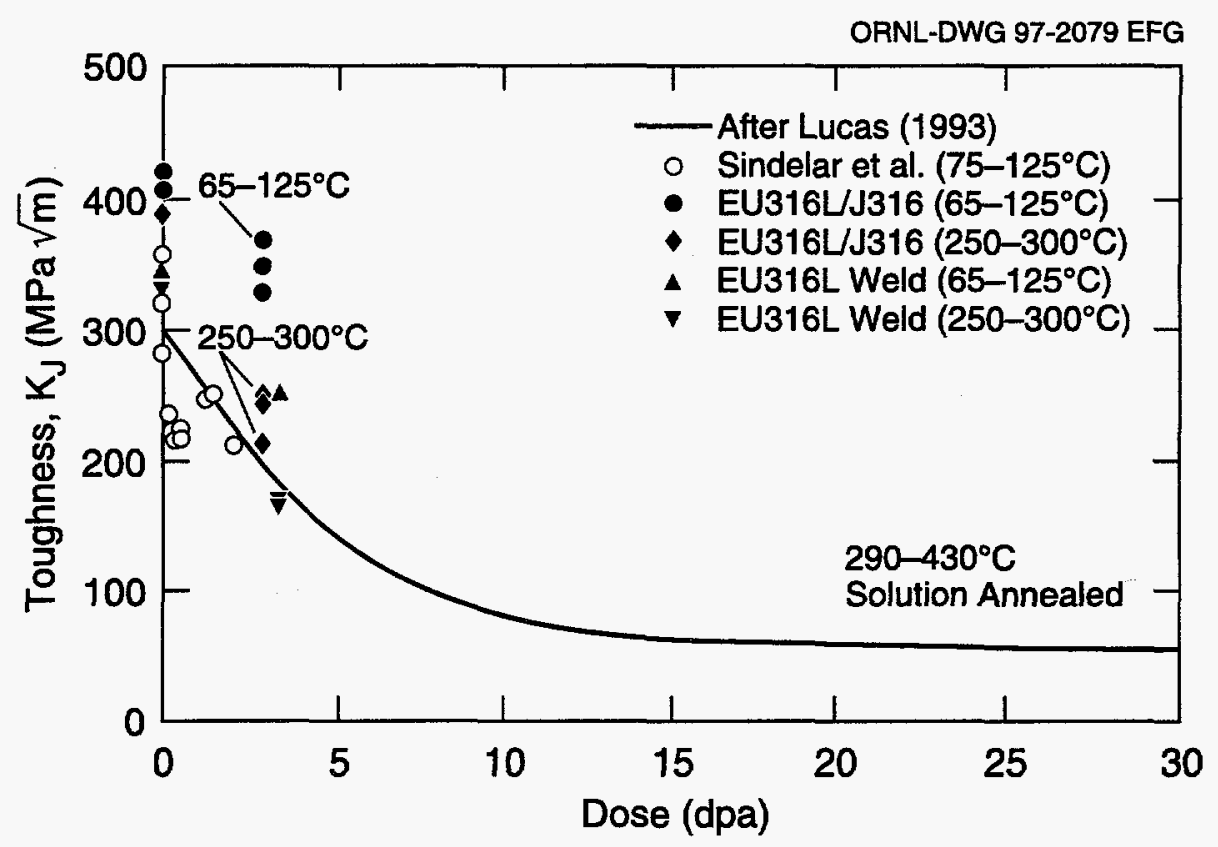

Fig. 3. Fracture toughness of 304 and 316 austenitic steels neutron irradiated and tested at temperatures shown.

\section{COMPONENTS THAT MAY BE CHALLENGED BY A CHANGE TO MOX FUEL}

Increased neutron flux levels and gamma and neutron heating rates that may result from use of MOX fuels may adversely affect some components, including the reactor pressure vessel and the internal components. Aging degradation studies for reactors using conventional fuel are suggested to be used as the starting point for evaluating the potential impact of converting to MOX fuels.

\subsection{REACTOR VESSEL}

The effects of radiation on reactor pressure vessels have received considerable attention because of the catastrophic consequences of a brittle fracture. Several Russian VVER-440 reactor vessels have been annealed in-situ to lower the transition temperature, which was approaching the minimum operating temperature of the vessel.

An annealing test was conducted on the canceled Marble Hill Plant reactor vessel to evaluate annealing of U.S. reactor vessels. Current thinking is that the transition temperature shift will not be large enough to restrict the operating life of the reactors being considered for burning MOX fuels because those reactors were designed so that the fast neutron flux in the vessel is lower than in some of the early reactors. Belgonucleaire $^{2}$ had Tractebel Engineering and Framatome review the impact of MOX fuel loading in light-water reactors (LWRs) on plant licensing. Two core management strategies were considered:

- yearly cycles with one-fourth core reload, and

- extended cycles with one-third core reload. 
One of the areas considered was reactor pressure vessel embrittlement. Because of the low recycling ratio, the review showed that the fast fluence on the pressure vessel is not increased with the MOX fuel core management.

Surveillance specimen results 8,31 from the High Flux Isotope Reactor (HFIR) indicated a more pronounced degradation of fracture toughness than expected, as shown in Fig. 4. An early theory for this discrepancy is that the thermal neutrons were responsible. A more recent explanation ${ }^{32}$ is that intense gamma rays enhanced the damage. It is likely that the spectral shift compared to other radiation experiments is a contributing factor. Thus, detailed studies are warranted to evaluate the possibility of an appreciably greater rate of embrittlement when MOX fuels are used.

Tables 1 and 2 from Ref. 11 give an overview of the aging issues for pressurized-water reactor (PWR) and boiling-water reactor (BWR) pressure vessels, respectively.

Because of the catastrophic consequences of a reactor vessel brittle fracture, a detailed study should be done to ensure that it will not be necessary to cease operation before vessel embrittlement becomes excessive.

\subsection{REACTOR INTERNALS}

Except for cases where failure of reactor internal components could be the initiator of a sequence of events that lead to failure of the reactor vessel, structural failure of reactor internals is not as catastrophic as failure of the reactor vessel because the reactor vessel would prevent release of radioactive debris. However, structural failure of internal components can have severe economic consequences. The fuel assemblies are not addressed in this report because extensive fuel assembly qualification is planned. The control rod drive mechanisms and other reactor internals are addressed.

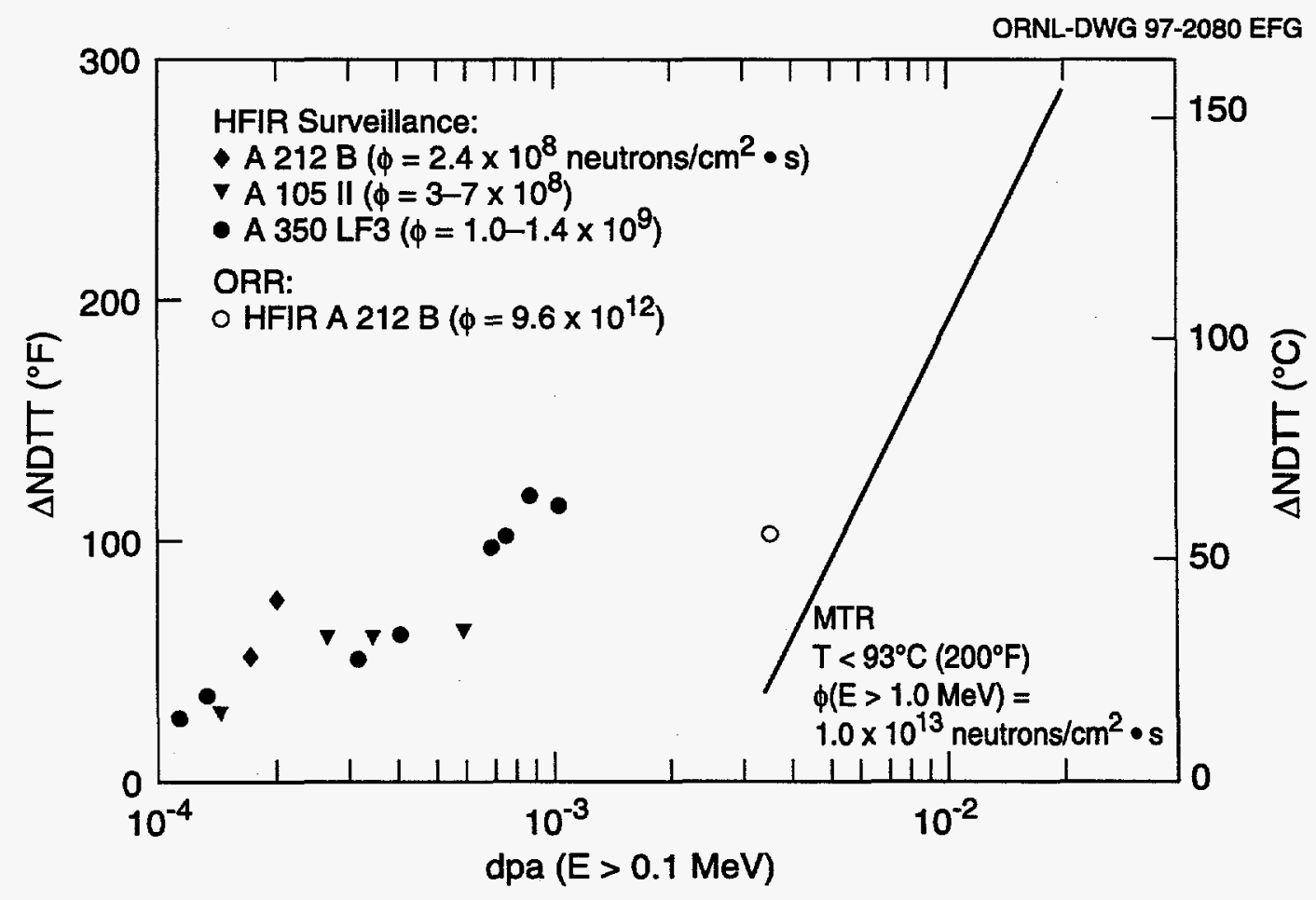

Fig. 4. Increase in NDTT with displacements per atom for irradiations in HFIR (vessel surveillance positions), ORR, and MTR. 
Table 1. Understanding and managing aging of PWR pressure vessels

\begin{tabular}{|c|c|c|c|}
\hline \multirow[b]{2}{*}{ Sites } & \multicolumn{2}{|c|}{ Understanding aging (materials, stressors, and environmental interactions) } & \multirow{2}{*}{$\begin{array}{c}\text { Managing aging } \\
\text { Mitigation }\end{array}$} \\
\hline & Materials & Aging concerns & \\
\hline Beltline region & $\begin{array}{l}\text { Low-alloy carbon steel } \\
\text { SA-533B-1, SA-508-2, SA-302B } \\
\text { Type } 308 \text { SS and 309 SS cladding }\end{array}$ & $\begin{array}{l}\text { Irradiation embrittlement } \\
\text { - Chemical composition of vessel } \\
\text { materials }(\mathrm{Cu}, \mathrm{Ni}, \mathrm{P}) \\
\text { - Drop in upper-shelf energy (USE) } \\
\text { - Shift in reference nil-ductility- } \\
\text { transition-temperature (RT } \text { NDT }_{\text {D }} \\
\text { Environmental fatigue }\end{array}$ & $\begin{array}{l}\text { Neutron flux reduction } \\
\text { inservice annealing } \\
\text { (ASTM E 509-86) } \\
\text { Determine effects of } \\
\text { annealing and } \\
\text { reembrittlement rate }\end{array}$ \\
\hline Outlet/inlet nozzles & $\begin{array}{l}\text { Submerged arc (granular flux- } \\
\text { Linde } 80,91,124, \text { and } 1092 \\
\text { manganese-molybdenum nickel } \\
\text { filler wire) narrow gap } \\
\text { submerged arc, shielded metal } \\
\text { arc, and electroslag welds }\end{array}$ & $\begin{array}{l}\text { Environmental fatigue } \\
\text { Irradiation embrittlement } \\
\text { Function of nozzle elevation }\end{array}$ & \\
\hline $\begin{array}{l}\text { Instrumentation nozzles } \\
\text { CRDM housing nozzles }\end{array}$ & & Environmental fatigue & \\
\hline Closure studs & SA-540, grade B24, Class 3 & $\begin{array}{l}\text { Environmental fatigue-preload cycles } \\
\text { during head replacement } \\
\text { Boric acid corrosion (if leakage occurs) }\end{array}$ & \\
\hline
\end{tabular}


Table 2. Understanding and managing aging of BWR pressure vessels

\begin{tabular}{|c|c|c|c|}
\hline \multirow[b]{2}{*}{ Sites } & \multicolumn{2}{|c|}{ Understanding aging (materials, stressors, and environmental interactions) } & \multirow{2}{*}{$\frac{\text { Managing aging }}{\text { Mitigation }}$} \\
\hline & Materials & Aging concerns & \\
\hline $\begin{array}{l}\text { Feedwater nozzles and safe end } \\
\text { welds }\end{array}$ & $\begin{array}{l}\text { SA-508-2 } \\
\text { Type } 304 \text { SS, Type } 316 \text { SS, Inconel } \\
\text { SB-166, Inconel SB-167, SA-508-1 }\end{array}$ & $\begin{array}{l}\text { High-cycle thermal fatigue caused } \\
\text { by feedwater leakage } \\
\text { Environmental fatigue }\end{array}$ & $\begin{array}{l}\text { Modify design, revise operating } \\
\text { procedures, and remove feedwater } \\
\text { nozzle cladding to prevent fatigue } \\
\text { cracking }\end{array}$ \\
\hline $\begin{array}{l}\text { Recirculation inlet/outlet } \\
\text { nozzles and dissimilar metal } \\
\text { welds }\end{array}$ & & $\begin{array}{l}\text { IGSCC crack initiated in HAZ may } \\
\text { propagate into base metal } \\
\text { Environmental fatigue }\end{array}$ & $\begin{array}{l}\text { Implement hydrogen water chemistry } \\
\text { to reduce IGSCC damage }\end{array}$ \\
\hline $\begin{array}{l}\text { Welds } \\
\text { - Control rod drive stub tubes } \\
\text { - Interior attachments }\end{array}$ & & $\begin{array}{l}\text { IGSCC crack initiated in HAZ may } \\
\text { propagate into base metal by } \\
\text { corrosion and/or environmental } \\
\text { fatigue }\end{array}$ & $\begin{array}{l}\text { Implement hydrogen water chemistry } \\
\text { to reduce IGSCC damage }\end{array}$ \\
\hline Beltline region & $\begin{array}{l}\text { Low-alloy carbon steel SA-533B-1, } \\
\text { SA-302B, Type } 308 \text { SS and } 309 \text { SS } \\
\text { cladding }\end{array}$ & $\begin{array}{l}\text { Irradiation embrittlement } \\
\text { - Chemical composition of vessel } \\
\text { materials (Cu, Ni, P) } \\
\text { - Drop in upper-shelf energy } \\
\text { (USE) } \\
\text { - Shift in reference nil-ductility- } \\
\text { transition-temperature (RT } \text { NDT) }_{\text {- }} \\
\text { - Welds are more susceptible than } \\
\text { base metal } \\
\text { - Flux is lower than that in PWR } \\
\text { vessel } \\
\text { Environmental fatigue }\end{array}$ & $\begin{array}{l}\text { Inservice annealing (ASTM E 509-86) } \\
\text { Determine effects of annealing and } \\
\text { reembrittlement rate } \\
\text { Implement neutron flux reduction } \\
\text { program }\end{array}$ \\
\hline Closure studs & $\mathrm{SA}-540$ grade $\mathrm{B} 22$ or $\mathrm{B} 23$ & $\begin{array}{l}\text { Environmental fatigue } \\
\text { - Preload cycles during head } \\
\text { replacement } \\
\text { Fretting }\end{array}$ & \\
\hline $\begin{array}{l}\text { External attachment welds such } \\
\text { as skirt supports }\end{array}$ & SA-193 grade B7 & $\begin{array}{l}\text { Low-cycle thermal and mechanical } \\
\text { fatigue }\end{array}$ & \\
\hline
\end{tabular}


The majority of reactor internals are made of type 304 stainless steel. Studies of the residual life of major LWR internal components identified corrosion, including stress corrosion cracking (SCC) and irradiation-assisted stress corrosion cracking (IASCC), fatigue, mechanical wear, erosion, embrittlement, creep, and stress relaxation as the primary aging-related degradation mechanisms. Of these, reported failure information and laboratory tests indicate that SCC, fatigue, and mechanical wear are the principal causes of aging degradation.

However, the aging-related degradation mechanisms that are most likely affected by converting to MOX fuels are IASCC, embrittlement, creep, and stress relaxation. Fatigue may also be impacted by higher thermal stresses because of the higher heating rates and flow-induced vibrations. The potential fatigue problems will not be discussed further here, but should be addressed.

The aging degradation studies examined documented failures of reactor internals to identify the important degradation mechanisms. Therefore, real problems were highlighted as opposed to hypothetical problems.

\subsubsection{PWRs}

The effects of fast neutron fluxes are most pronounced in regions near the core. Reactor internals such as core baffle, core barrel, thermal shield, surveillance specimen holder tubes, core support plates, and incore instrumentation guide tubes are susceptible to irradiation-assisted SCC and radiation-induced embrittlement.

The thimble tubes, the high-strength steel bolts used on the reactor internals, the thermal shield, and the core barrel are subject to high-cycle fatigue damage caused by flow-induced vibrations. The highstrength fasteners are also subject to SCC and stress relaxation caused by neutron irradiation. Other degradation mechanisms acting on the reactor internals are irradiation and thermal embrittlement, wear, and fretting. Potential (and actual) failure modes for reactor internals include leakage from a thinned thimble tube (a breach in the primary pressure boundary), broken bolts, loose parts, and fuel damage from baffle jetting. Table 3 summarizes the aging concerns for PWR reactor internals.

\subsubsection{BWRs}

Table 4 gives a summary of aging issues for BWR reactor internals. Several BWR reactor internalsfor example, jet pumps, feedwater spargers, fasteners, and the core plate-have highly stressed materials with chromium-depleted grain boundaries, crevices, or cold work, and are susceptible to intergranular stress corrosion cracking (IGSCC). The heat-affected zones of the welds that attach the reactor internals to the pressure vessel are also susceptible to IGSCC, and cracks caused by IGSCC may propagate into the pressure vessel base metal. The top guide structure and core shroud are exposed to relatively high fast neutron fluences and are susceptible to IASCC, which may occur at relatively low stresses. The jet pumps and feedwater spargers are susceptible to high-cycle fatigue caused by flow-induced vibrations. Cast stainless steel components, such as orificed fuel support pieces, may experience both thermal and irradiation embrittlement.

Greene ${ }^{33,34}$ studied the aging of BWR control rod drive systems. The primary causes of control rod drive mechanism (CRDM) aging were identified as embrittlement, fatigue fracture, and thermal degradation of the graphitic seals, nitrided surface corrosion, mishandling and rebuilding errors occurring during CRDM maintenance, and, to a lesser extent, improper storage support.

Radiation-induced degradation is suspected to be the cause of certain effects observed in the spud, the CRDM component that engages the control rod assembly blade via the uncoupling rod. There have been reports of the "fingers" of this Inconel X-750 component being easily bent after a prolonged service history $(>15$ years) in the reactor vessel. 
Table 3. Understanding and managing aging of PWR reactor internals

\begin{tabular}{|c|c|c|c|}
\hline \multirow[t]{2}{*}{ Sites } & \multicolumn{2}{|c|}{$\begin{array}{c}\text { Understanding aging (materials, stressors, and } \\
\text { environmental interactions) }\end{array}$} & \multirow{2}{*}{$\frac{\text { Managing aging }}{\text { Mitigation }}$} \\
\hline & Materials & Aging concerns & \\
\hline $\begin{array}{l}\text { Instrument tubes (flux } \\
\text { thimble tubes) }\end{array}$ & Type 304 SS & $\begin{array}{l}\text { Fretting, wear, high-cycle } \\
\text { fatigue }\end{array}$ & $\begin{array}{l}\text { Use thicker-walled or double- } \\
\text { walled thimble tubes (W plants) }\end{array}$ \\
\hline Bolts and pins & $\begin{array}{l}\text { Type } 316 \text { SS } \\
\text { Alloy A-286 }\end{array}$ & $\begin{array}{l}\text { IGSCC, high-cycle fatigue, } \\
\text { stress relaxation }\end{array}$ & $\begin{array}{l}\text { Reduce preloads on high-strength } \\
\text { bolts to mitigate IGSCC }\end{array}$ \\
\hline $\begin{array}{l}\text { CRGT split pins and } \\
\text { radial support key } \\
\text { bolts }(\underline{W})\end{array}$ & Alloy X-750 & IGSCC & $\begin{array}{l}\text { Use improved heat treatments for } \\
\text { Alloy X-750 High-strength } \\
\text { bolting materials to reduce } \\
\text { IGSCC susceptibility }\end{array}$ \\
\hline Thermal shield & Type 304 SS & $\begin{array}{l}\text { High-cycle fatigue, irradiation } \\
\text { embrittlement, distortion }\end{array}$ & \\
\hline $\begin{array}{l}\text { Core barrel, baffles, } \\
\text { and formers }\end{array}$ & Type 304 SS & $\begin{array}{l}\text { High-cycle fatigue, irradiation } \\
\text { embrittlement }\end{array}$ & $\begin{array}{l}\text { Remove thermal shields (or } \\
\text { replace with neutron shield } \\
\text { panels on exterior of core }\end{array}$ \\
\hline $\begin{array}{l}\text { Upper and lower core } \\
\text { support structures }\end{array}$ & Type 304 SS & $\begin{array}{l}\text { Irradiation embrittlement, } \\
\text { corrosion-fatigue }\end{array}$ & $\begin{array}{l}\text { barrels) for designs that have } \\
\text { experienced bolt failures }\end{array}$ \\
\hline $\begin{array}{l}\text { Flow mixer and } \\
\text { cruciform instrument } \\
\text { guides (some early } \\
\underline{\text { W plants) }}\end{array}$ & $\begin{array}{l}\text { Cast SS (grade CF-8) } \\
\text { (some early } \underline{\mathrm{W}} \\
\text { plants) }\end{array}$ & $\begin{array}{l}\text { Thermal (ferrite phase) and } \\
\text { irradiation (austenite phase) } \\
\text { embrittlement }\end{array}$ & $\begin{array}{l}\text { Use one-piece thermal shields } \\
\text { rather than multipiece designs } \\
\text { (RPVs in some older } \underline{W} \text { plants } \\
\text { have inadequate access for one- } \\
\text { piece installation) }\end{array}$ \\
\hline $\begin{array}{l}\text { Holddown spring (W } \\
\text { and } \mathrm{CE})\end{array}$ & Type 403 SS & Stress relaxation & \\
\hline
\end{tabular}


Table 4. Understanding and managing aging of BWR reactor internals

\begin{tabular}{|c|c|c|c|c|}
\hline \multirow{2}{*}{\multicolumn{2}{|c|}{ Sites }} & \multicolumn{2}{|c|}{$\begin{array}{l}\text { Understanding aging (materials, stressors, and environmental } \\
\text { interactions) }\end{array}$} & \multirow{2}{*}{$\begin{array}{c}\text { Managing aging } \\
\text { Mitigation }\end{array}$} \\
\hline & & Materials & Aging concerns & \\
\hline \multicolumn{2}{|c|}{ Attachment welds to reactor vessel } & Alloy 182 & IGSCC, corrosion-fatigue & $\begin{array}{l}\text { Maintain strict control on coolant impurities } \\
\text { to keep conductivity below } 0.2 \mu \mathrm{S} / \mathrm{cm}\end{array}$ \\
\hline \multicolumn{2}{|c|}{ Core plate, core shroud } & Type 304 SS & $\begin{array}{l}\text { IGSCC, irradiation-assisted SCC } \\
\text { (IASCC) }\end{array}$ & \multirow{2}{*}{$\begin{array}{l}\text { Use hydrogen water chemistry to suppress } \\
\text { dissolved oxygen in coolant from typical } \\
200 \text { ppb to below } 20 \mathrm{ppb} \text { to mitigate } \\
\text { IGSCC }\end{array}$} \\
\hline \multirow[t]{3}{*}{ Jet pumps } & Holddown beams & $\mathrm{X}-750$ & IGSCC, high-cycle fatigue & \\
\hline & $\begin{array}{l}\text { Riser support braces } \\
\text { Welds }\end{array}$ & $\begin{array}{l}\text { Type } 304 \text { SS } \\
\text { Type } 308 \text { SS }\end{array}$ & $\begin{array}{l}\text { High-cycle fatigue } \\
\text { IGSCC }\end{array}$ & \multirow{2}{*}{$\begin{array}{l}\text { Assess effect of hydrogen water chemistry on } \\
\text { - IASCC } \\
\text { - fatigue crack growth } \\
\text { - radiation fields } \\
\text { - fuel performance }\end{array}$} \\
\hline & Castings & Grade CF-8 SS & $\begin{array}{l}\text { Thermal embrittlement, IGSCC } \\
\text { (if ferrite content is low) }\end{array}$ & \\
\hline \multicolumn{2}{|l|}{ Top guide } & Alloy Type 304 SS & IASCC, IGSCC & \multirow{7}{*}{$\begin{array}{l}\text { For replacement components } \\
\text { - reduce preload stresses } \\
\text { - use high-temperature annealing and age } \\
\text { - hardening of Alloy X-750 material } \\
\text { - remove crevices }\end{array}$} \\
\hline \multicolumn{2}{|c|}{ Core spray and feedwater spargers } & Type 304 SS & IGSCC, corrosion-fatigue & \\
\hline \multicolumn{2}{|c|}{ Orificed fuel supports } & Grade CF-8 SS & $\begin{array}{l}\text { IGSCC, thermal and irradiation } \\
\text { embrittlement, IASCC }\end{array}$ & \\
\hline \multicolumn{2}{|c|}{ Peripheral fuel supports } & Type 304 and 304L SS & IGSCC, IASCC & \\
\hline \multicolumn{2}{|c|}{ Baffle plate access hole covers } & Alloy 600 & IGSCC (crevices) & \\
\hline \multicolumn{2}{|c|}{ Shroud head bolts } & Alloy 600 & IGSCC (crevices) & \\
\hline \multicolumn{2}{|c|}{ Neutron monitor dry tubes } & Alloy 600 , Type 304 SS & IGSCC (crevices), IASCC & \\
\hline
\end{tabular}




\section{CONCLUSIONS}

The impact of conversion to MOX fuels is expected to be manageable but must be addressed to ensure safe and reliable operation. There is a continual need to maintain a high plant capacity and availability in the face of the aging phenomena even when conventional fuels are used. It should be noted that an active European network in structural integrity ${ }^{35}$ is addressing these issues for both reactor pressure vessels and reactor internal components.

\section{REFERENCES}

1. DOE Plutonium Disposition Study, "Core Designs for Existing ABB-CE System 80 Reactors for the Disposition of Weapons-Grade Plutonium, A Final Report," ABB-Combustion Engineering, October 25, 1996.

2. J. Van Vyve, "A Utility's Experience: Licensing and Use of MOX Fuel," presented at Belgonucleaire Seminar, Belgian Embassy, Washington, D.C., July 9, 1996.

3. R. E. Stoller, Modeling the Influence of Irradiation Temperature and Displacement Rate on Radiation-Induced Hardening in Ferritic Steels, NUREG/CR-5859 (ORNL/TM-12073), Lockheed Martin Energy Systems, Inc., Oak Ridge National Laboratory, July 1992.

4. W. E. Pennell, "Aging Impact on the Safety and Operability of Nuclear Reactor Pressure Vessels," Proceedings of the Aging Research Information Conference, NUREG/CP-0122, Vol. 1, pp. 431453, U.S. Nuclear Regulatory Commission, March 1992.

5. T. L. Dickson and F. A. Simonen "The Application of Probabilistic Fracture Analysis to Residual Life Evaluation of Embrittled Reactor Vessels," Proceedings of the Aging Research Information Conference, NUREG/CP-0122, Vol. 1, pp. 454-467, U.S. Nuclear Regulatory Commission, March 1992.

6. R. D. Cheverton, W. E. Pennell, G. C. Robinson, and R. K. Nanstad, Impact of Radiation Embrittlement on Integrity of Pressure Vessel Supports for Two PWR Plants, NUREG/CR-5320 (ORNL/ TM-10966), Martin Marietta Energy Systems, Inc., Oak Ridge National Laboratory, January 1989.

7. R. D. Cheverton, J. G. Merkle, and R. K. Nanstad (Eds.), Evaluation of HFIR Pressure-Vessel Integrity Considering Radiation Embrittlement, ORNL/TM-10444, Martin Marietta Energy Systems, Inc., Oak Ridge National Laboratory, April 1988.

8. R. K. Nanstad et al., "Effects of $50^{\circ} \mathrm{C}$ Surveillance and Test Reactor Irradiation on Ferritic Pressure Vessel Steel Embrittlement," presented at 14th International Symposium on the Effects of Radiation on Materials, Andover, Mass., June 27, 1988, to be published in ASTM STP.

9. K. Luk, "Reactor Internals Degradation Mechanisms," Proceedings of the Eighteenth Water Reactor Safety Information Meeting, Vol. 3, NUREG/CP-0114, pp. 453-483, U.S. Nuclear Regulatory Commission, April 1991.

10. K. H. Luk, Pressurized-Water Reactor Internals Aging Degradation Study-A Phase I Report, NUREG/CR-6048 (ORNL/TM-12371), Martin Marietta Energy Systems, Inc., Oak Ridge National Laboratory, 1993.

11. Nuclear Plant Aging Research (NPAR) Program Plan Status and Accomplishments, NUREG1144, Rev. 2, U.S. Nuclear Regulatory Commission, June 1991.

12. V. N. Shah and P. E. MacDonald, Residual Life Assessment of Major Light Water Reactor Components-Overview, Volume 1, NUREG/CR-4731, (EGG-2469), Vol. 1, EG\&G Idaho, June 1987.

13. V. N. Shah and P. E. MacDonald (Eds.), Residual Life Assessment of Major Light Water Reactor Components-Overview, NUREG/CR-4731, (EGG-2469), Vol. 2, EG\&G Idaho, November 1989.

14. J. F. Copeland, Component Life Estimation: LWR Structural Materials Degradation Mechanisms, EPRI NP-5461, prepared by Structural Integrity Associates, Inc., for the Electric Power Research Institute, September 1987.

15. Degradation and Failure of Bolting in Nuclear Power Plants, Vol. 1, EPRI NP-5769, prepared by Applied Science \& Technology for the Electric Power Research Institute, 1988. 
16. M. L. Grossbeck, L. K. Mansur, and M. P. Tanaka, "Irradiation Creep in Austenitic Stainless Steels at 60 to $400^{\circ} \mathrm{C}$ with a Fusion Reactor Helium to dpa Ratio," Effects of Radiation on Materials: 14th International Symposium (Vol. 2), American Society for Testing and Materials, Philadelphia, 1990.

17. L. R. Greenwood, "A New Calculation of Thermal Neutron Damage and Helium Production in Nickel," J. Nucl. Mater., 115, 137-142 (1983).

18. G. E. Lucas, "The Evolution of Mechanical Property Change in Irradiated Austenitic Stainless Steels," J. Nucl. Mater, 206, 287-305 (1993).

19. K. Farrell, P. J. Maziasz, E. H. Lee, and L. K. Mansur, "Modification of Radiation Damage Microstructure by Helium," Radiat. Eff., 78, 277-295 (1983).

20. R. E. Robbins, J. J. Holmes, and J. E. Irvin, "Post Irradiation Tensile Properties of Annealed and Cold-Worked AISI-304 Stainless Steel," Trans. Am. Nucl. Soc. (November 1967).

21. O. K. Chopra and H. M. Chung, "Long-Term Aging of Cast Stainless Steel: Mechanisms and Resulting Properties," Proceedings of the Fifteenth Water Reactor Safety Research Information Meeting, Gaithersburg, Maryland, NUREG/CP-0090, U.S. Nuclear Regulatory Commission, October 1987.

22. O. K. Chopra, Estimation of Fracture Toughness of Cast Stainless Steels During Thermal Aging in LWR Systems, NUREG/CR-4513, Argonne National Laboratory, June 1991.

23. L. C. Walters and W. E. Ruther, "In-Reactor Stress Relaxation of Inconel X-750 Springs," $J$. Nucl. Mater., 68, 324-333 (1977).

24. A. J. Jacobs, G. P. Wozadlo, K. Nakata, T. Yoshida, and I. Masaoka, "Radiation Effects on the Stress Corrosion and Other Selected Properties of Type 304 and Type 316 Stainless Steels," Environmental Degradation of Materials in Nuclear Power Systems-Water Reactors, G. J. Theus and J. R. Weeks (Eds.), The Metallurgical Society, pp. 673-681, 1988.

25. A. J. Jacobs and G. P. Wozadlo, "Irradiation-Assisted Stress Corrosion Cracking as a Factor in Nuclear Power Plant Aging," J. Mater. Eng., 9(4) (1988).

26. H. Hanninen and I. Aho-Mantila, "Environment-Sensitive Cracking of Reactor Internals," Environmental Degradation of Materials in Nuclear Power Systems-Water Reactors, G. J. Theus and J. R. Weeks (Eds.), The Metallurgical Society, pp. 77-92, 1988.

27. K. S. Brown and G. M. Gordon, "Effects of BWR Coolant Chemistry on the Propensity for IGSCC Initiation and Growth in Creviced Reactor Internals Components," Environmental Degradation of Materials in Nuclear Power Systems-Water Reactors, G. J. Theus and J. R. Weeks (Eds.), The Metallurgical Society, pp. 243-248, 1988.

28. T. F. Kassner, W. E. Ruther, H. M. Chung, P. D. Hicks, A. G. Hins, J. Y. Park, and W. J. Shack, "Fatigue and Environmentally Assisted Cracking in Light Water Reactors," Proceedings of the Nineteenth Water Reactor Safety Information Meeting, NUREG/CP-0119, Vol. 1, pp. 127-150, U.S. Nuclear Regulatory Commission, April 1992.

29. ASME Boiler and Pressure Vessel Committee, "ASME Boiler and Pressure Vessel Code, Section III: Division I-Appendices, Article G-2000, Vessels," The American Society of Mechanical Engineers, New York, 1992.

30. K. Farrell, Radiation Effects in the Stainless Steel Primary Coolant Supply Adapter, ORNL/TM13064, Lockheed Martin Energy Systems, Inc., Oak Ridge National Laboratory, August 1995.

31. R. D. Cheverton and R. K. Nanstad, Evaluation of HFIR Vessel Surveillance Data and Hydro Test Conditions, ORNL/TM-12758, Oak Ridge National Laboratory, August 1994.

32. R. E. Johnson and R. E. Lipinski, Radiation Effects on Reactor Pressure Vessel Supports, NUREG-1509, U.S. Nuclear Regulatory Commission, May 1996.

33. R. H. Greene, Aging and Service Wear of Control Rod Drive Mechanisms for BWR Nuclear Plants, NUREG/CR-5699 (ORNL-6666), Martin Marietta Energy Systems, Inc., Oak Ridge National Laboratory, Vol. 1, November 1992.

34. R. H. Greene, "Aging Assessment of BWR Control Rod Drive Systems," Proceedings of the Nineteenth Water Reactor Safety Information Meeting, NUREG/CP-0119, Vol. 1, pp. 343-361, U.S. Nuclear Regulatory Commission, April 1992.

35. U. von Estorff, S. Crutzen, R. C. Hurst, P. Lemaitre, B. Hemsworth, L. M. Davies, and F. Champigny, "European Networks in Structural Integrity-Status in 1995," Nucl. Eng. Des., 165, 181197 (1996). 


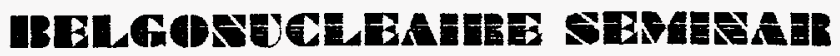

\section{A UTILITY'S EXPERIENCE : LICENSING \& USE OF MOX FUEL}

Jean VAN VYVE

TRACTEBEL

\begin{abstract}
This paper presents an overview of the work performed to license the introduction of MOX fuel in two nuclear units, in the frame of the spent fuel recycling policy applied in Belgium. It summarizes also the experience feedback to date with MOX utilization.
\end{abstract}




\section{INTRODUCTION - BELGIAN NUCLEAR CONTEXT}

The Belgian Utility ELECTRABEL operates seven PWR nuclear reactors located on two sites (see Table 1). These units are all operated as baseload plants and supply presently about $55 \%$ of the electricity produced in Belgium. Belgium is one of the top nuclear countries in that sense, including for plant performance : these units have experienced an average load factor of $85 \%$ from industrial operation. Three of them have also been uprated (4 to $10 \%$ thermal uprating ; 7 to $11 \%$ electrical uprating), partly through steam generator and low pressure turbine rotors replacements.

To best fit the grid power demand diagram, four units are operated in extended cycles (15 to 18 months, corresponding to 425 to 510 EFPD) and the three others in yearly cycles ( 325 EFPD), the target load factor being 89 to $92 \%$ yearly average.

The spent fuel discharged between start up and 1990 from three units (Doel 1, Doel 2, Tihange 1) is currently reprocessed. Part of the plutonium has been recycled in the fast breeder reactor programs in which ELECTRABEL has participated.

Under the current reprocessing contract signed by SYNATOM with COGEMA, about 4.7 tons of $\mathrm{Pu}$ will be recovered between the years 1990 and 2000 . Considering that the fast breeder reactors option is delayed, three potential destinations exist for this plutonium :

- the irradiation in PWRs, under the form of MOX fuel ;

- the intermediate storage, with later irradiation in fast breeder reactors, after purification ;

- the final storage.

The detailed evaluation of the three options clearly showed that the first one - immediate recycling as MOX fuel - was the best solution on the technical, economical and nonproliferation points of view.

In fact it is the only option that has reached an industrial development stage, and MOX fuel irradiation has been successfully and safely done for about 20 years in commercial reactors in France, Germany and Switzerland.

On the economical point of view, a study performed in 1990 upon the request of the Ministry of Economy clearly showed that a non recycling option of the recovered Pu would lead to 2 to 5 billion BEF (60 to 150 million USD) overcosts compared to MOX recycling. These overcosts essentially result from the necessity to condition, store, control and dispose off the non recycled $\mathrm{Pu}$.

\section{MOX RECYCLING PROGRAM AND FUEL MANAGEMENT}

\subsection{Program design bases}

The MOX recycling program considers Pu recycling in line with the Pu recovery schedule, to avoid intermediate plutonium accumulation and aging. Typically the plutonium is loaded in the reactor 3 years after having been produced at La Hague. 
Similarly, the main design objective for the study was that MOX loading must allow a safe operation of the plant and should not require modifications in the plant design and plant operation. In particular, the number of control rods clusters in core should not be increased and the in-core fuel management should not be modified, to minimize the costs.

The following basic assumptions of the MOX program proceed from this design objective :

- recycling of MOX fuel assemblies will take place in two plants in order to burn the recovered plutonium with a recycling ratio of about $20 \%$, low enough to avoid important core perturbation ;

- the two plants - Doel 3 and Tihange 2- are of the FRAMATOME 900 MWe type and are similar to the French plants in which plutonium is recycled;

- one MOX fuel assembly design will be developed even if the operation strategies (enrichment of U-bearing fuel, cycle length, ...) of the two plants are different ;

- the discharge burnup of the MOX fuel assemblies will be similar to the discharge burnup of $U$ fuel assemblies : $45000 \mathrm{MWd} / \mathrm{tHM}$. This is significantly higher than the current irradiation level in France or Germany ;

- the MOX fuel assemblies will be directly stored under water and not in the dry storage area; so minimizing exposure and diversion risks ;

- the existing procurement policy (concurrent loading of $\mathrm{U}$ and MOX fuel of different vendors) must be kept.

\subsection{Fuel design and management}

The MOX fuel design is based on plutonium coming from the reprocessing of $\mathrm{UO}_{2}$ fuel irradiated to $45000 \mathrm{MWd} / \mathrm{tU}$ in a $900 \mathrm{MWe}$ plant. The isotopic composition used for the studies is as follows:

$\begin{array}{lr}\text { Pu 238 } & 2.6 \% \\ \text { Pu 239 } & 53.4 \% \\ \text { Pu 240 } & 23.9 \% \\ \text { Pu 241 } & 11.7 \% \\ \text { Pu 242 } & 7.3 \% \\ \text { Am 241 } & 1.1 \%\end{array}$

The Pu content of the MOX fuel assembly is chosen to obtain an energetic equivalence to a $\mathrm{UO}_{2}$ fuel assembly enriched to $3.8 \%$ in U235. With the isotopic composition given here above, the total Pu content is $7.7 \%$, or $5 \%$ fissile Pu. The fuel assembly is composed of three zones with different Pu content - lower at the periphery - to control the peaking factor at the $\mathrm{MOXJO}_{2}$ interface. The map of the fuel assembly is shown on Fig. 1.

The contract signed with FRAGEMA foresees the supply of 144 MOX fuel assemblies of advanced structural design (AFA-2G) between 1995 and 2002 . Most of the fabrication work is performed in Belgium by BELGONUCLEAIRE and FBFC-International. Uranium fuel is presently supplied by SIEMENS/KWU in Doel 3 and by ABB-Atom in Tihange 2 with full compatibility between fuel types. 
In-core fuel management applied in Doel 3 and Tihange 2 has not been changed with MOX fuel loading from the one applied for previous cycles with uranium fuel, in terms of cycle length, reload size and peaking factors.

The main data on the in-core fuel management presently applied in the two units are given in Table II. As this table identifies, Tinange 2 and Doel 3 were uprated making Doel 3 the most powerful 3-loop plant in the world. However, this was shown to have no adverse effect on the MOX fuel rod design, provided that MOX fuel assemblies are located at the core periphery at the end of irradiation (IN-OUT loading scheme).

The loading pattern of Tihange 2 (equilibrium cycle) is given on Fig. 2 . It combines simultaneous loading of poisoned $\mathrm{UO}_{2}$ fuel (Gadolinia rods with $8 \% \mathrm{Gd}_{2} \mathrm{O}_{3}$ ) and $\mathrm{MOX}$ fuel assemblies.

\section{LICENSING EFFORT AND TIME SCHEDULE}

\subsection{Extent of the licensing work}

Clearly, the design objectives were to minimize the licensing effort, the associated risk and costs and the operational constraints.

Meanwhile, the Belgian Safety Authorities requested that a full licensing process should be conducted, with a complete review of the FSAR of the plants, considering that introducing MOX fuel was a major change to the original plant design and licensing.

This review performed by TRACTEBEL ENGINEERING and FRAMATOME addressed the impact of MOX fuel loading on the following areas :

- fuel and core design ;

- transients and accidents safety analyses ;

- normal and accidental activity releases;

- radiological exposure ;

- waste treatment systems design;

- reactor pressure vessel embrittlement ;

- fuel handling.

It also verified the licensing of all plutonium and MOX fuel transport and fabrication steps in Belgium.

Two core management strategies were considered, to cover the existing options :

- $\quad$ yearly cycles with $1 / 4$ core reload strategy ;

- $\quad$ extended cycles with 1/3 core reload strategy. 
The in-core fuel management and safety evaluation studies were performed by FRAMATOME for the two core management strategies. Only a few accidents (large LOCA, Large Steam Line Break, Rod Ejection, Rod withdrawal-reactor Subcritical, Rod Drop) had to be reassessed, with consideration of MOX fuel in the core.

Thanks to the low recycling ratio, the review showed that :

- the neutronic characteristics of the core are only slightly modified ;

- the existing control rods can easily satisfy the shutdown margin requirements ;.

- all the safety criteria are met;

- the fast fluence on the pressure vessel is not increased with the MOX fuel core management ;

- the functional capabilities of plant systems are not impaired;

- the plant operation is not affected;

- the activity release to the public in normal and accidental conditions is almost not modified;

- the total collective exposure of the plant personnel is increased by $1 \%$ only ;

- all fabrication and transport steps are performed with licensed and well qualified equipment and plants.

On the fuel design point of view, FRAGEMA was able to demonstrate that all the fuel design criteria are met, provided that the active length of the fuel is reduced by $1 \%$, to increase the plenum volume for fission gas release.

\subsection{Licensing schedule}

As said eartier, a full licensing process was conducted for this project. In Belgium, this process is managed by a Special Commission composed of representatives of the Public Health, Environment and Employment Administrations, of scientific experts and of a representative of the Technical Advisory Body, competent in the field of Nuclear Safety. The Special Commission is also in charge of collecting the advises resulting from the public inquiry at the local, regional and federal levels.

A public review was decided and conducted at the political level on the back end issues (use of MOx fuel and management of the spent fuel) in parallel with the administrative licensing process. This obviously slowed down somewhat the licensing process.

In total, the licensing process lasted about 5 years, from start-up of the feasibility study to the first loading of MOX fuel. This process is summarized in Table III.

The last one and a half year were dedicated to final fuel and core design verification, to take power upratings into account, and to final update of the FSAR.

\section{ON-SITE IMPLEMENTATION}

\subsection{Plant update}

As MOX fuel introduction did not modify the plant essential systems, most of the work performed on site concerned the following aspects : 
- plant Technical Specification Update ;

- operators and plant personnel training on MOX fuel specificities, specific handling procedures for Mox fuel and specific safeguards ;

- installation of a specific equipment to detect potential alpha contamination in the air of the fuel building ;

- installation of the surveillance equipment related to the specific safeguards program for MOX fuel agreed upon with EURATOM;

- modification in the fuel handling area (remote video inspection equipment and motorised plug for access to the spent fuel pool in Tihange 2).

\subsection{Safeguards}

All Plutonium in Belgium is under strict international safeguards. As founding member of EURATOM, Belgium has handed over since 1959 the responsibility for safeguards within its own territory to the Community's executive body, the Commission. As such nuclear materials in Belgium were subjected to international safeguards right after the start of the first multinational nuclear safeguards system established by EURATOM. On May 2, 1975, Belgium has ratified the NPT, but already in 1973 EURATOM and the non-nuclear-weapon Member States of the Community, including Belgium, have signed an agreement with the IAEA on implementation of the safeguards provisions as stated by the NPT. Through this agreement, often referred to as the Verification Agreement (INFCIRC/193), both the EURATOM and IAEA safeguards principles are applied in Belgium. The Verification Agreement entered in Belgium into force on February 21, 1977. The implementation of the safeguards is described in the Commission Regulation $3227 / 76$. The safeguards systems implemented by the operators of nuclear facilities in Belgium are in full accordance to this Regulation and are described in Particular Safeguards Provisions.

The safeguards approach for unirradiated MOX fuel in Belgian PWRs is based on the New Partnership Approach (NPA) between IAEA and EURATOM. The arrangements for unirradiated MOX fuel assemblies in LWRs involve one physical inventory verification, up to twelve intermittent routine inspections at monthly intervals for timeliness purposes and those inspections necessary for verification of receipts. Inspections are executed by EURATOM and/or IAEA inspectors, accompanied by an inspector of the Nuclear Security Service of the Belgian Ministry of Justice.

The fresh MOX fuel assemblies are in Belgium transported by road in sealed containers from the fabrication plant in Dessel to the nuclear reactor sites. In presence of the EURATOM/IAEA inspectors the MOX fuel containers are unloaded and unsealed. After receipt of the MOX fuel assemblies, the assemblies are immediately stored under water in a dedicated area of the spent fuel pond where they are placed under permanent short interval surveillance by under water and water surface monitoring cameras. All MOX fuel assembly manipulations must be executed in the presence of EURATOM/IAEA inspectors, and during execution all possible MOX fuel assembly routing schemes are permanently monitored by adequate $\mathrm{C} / \mathrm{S}$ systems. 


\section{FUEL HANDLING}

Another important part of the project implementation is related to the MOX fuel assemblies reception at the plant. Regarding the important gamma and neutron dose rates projected for Mox fuel assemblies (see Table IV) compared to uranium fuel, and the potential risk of alpha contamination in case of fuel defect, the Safety Authorities requested to implement the following :

- Evaluate the full safety of handling MOX fuel in the fuel access area and, if needed, implement the necessary modification. This could cover such aspects as fuel handling equipment, ventilation, shielding, radiation monitoring.

- Proceed to a detailed review of the handling process so as to minimize the radiation exposure, establish specific handling procedures and perform a full scale blank test with the actual container and a dummy fuel assembly.

- Install additional shielding, if needed.

- Install specific monitoring equipment to detect a potential alpha contamination in the air.

- Provide the personnel with adequate gamma and neutron radiation monitoring devices.

The detailed review of the handling process showed that fuel access building and equipment could be used mostly as is, with only minor modification in Tihange 2 , were it was decided to modify the normal handling process, with direct introduction of the MOX fuel in the spent fuel building, reducing by this the total handling time and operators exposure. The access plug was motorized to ease the manipulations.

In the two plants, a detailed ALARA type review of the handling process was performed, to evaluate the individual contributions of each handling step to the total dose rate. This approach helped optimizing the handling process. It has to be noted that no additional shielding was installed in the plants, as good practice measures showed to be at least as efficient to minimize the total exposure to the plant personnel since efficient shielding against neutron flux, which contributes to about $50 \%$ of the dose rate, is necessarily bulky. which tends to complicate the handling process. The only specific equipment finally installed is a remote video inspection equipment of the fuel assemblies.

The total collective exposure was initially estimated to be 18 man-mSv for the reception of 8 MOX fuel assemblies, based on a preliminary analysis. It was reduced to 7.7 man-mSv after detailed ALARA review and finally to 5 man-mSv after a full testing of the handling process with a container and a dummy assembly.

\section{OPERATING EXPERIENCE}

Two batches of MOX fuel have been delivered and loaded so far in both units. First batch has a total $\mathrm{Pu}$ content of $6.70 \%(4.60 \%$ fissile $\mathrm{Pu})$ while figures for the second batch are $7.28 \%$ total Pu (4.85\% fissile Pu).

End of June, Doel 3 and Tihange 2 have restarted for their second cycle with MOX fuel. There are now $16 \mathrm{MOX}$ fuel assemblies in the core of Doel 3 and 20 in Tinange 2.

End of first cycle burnup of MOX fuel was $17000 \mathrm{MWd} / \mathrm{tHM}$. 
Main experience feed back is as follows :

(a) Core physical tests at beginning of cycle

Calculated parameters are all well within tolerance limits compared to measured values. This is particularly true for critical boron concentration (max. $30 \mathrm{ppm}$ difference) and kinetic parameters.

\section{(b) Core follow up}

Except some difficulties with activity rates in MOX fuel (more difficult to predict with the high $\mathrm{Pu}$ content in the center of the fuel assembly), other parameters are well predicted, notably power distribution and boron letdown curve (see Fig. 3 for Tihange 2 - first cycle with MOX fuel).

A total of 25 in-core flux maps have been processed so far.

\section{(c) Plant operation}

Both plants have worked as planned, Tihange 2 achieving a $98.3 \%$ availability factor during the first cycle with MOX fuel, with a load factor of $95.4 \%$.

The reinforced surveillance set up on core follow-up by the Safety Authorities during the first cycle is no more applied. So, plant operation is identical to another unit.

\section{(d) MOZ fuel handling}

Actual total collective exposure for reception of $8 \mathrm{MOX}$ fuel assemblies is equal to 3.5 man-mSv, and the transport and handling process is now routinely applied.

\section{CONCLUSION}

The most economical and technically suitable recycling process in Belgium for the plutonium coming from the reprocessing is clearly to use it as MOX fuel assemblies in PWR power reactors immediately after production. Belgian industry never changed its position on this matter and succeeded, after a long and often difficult political debate, in getting the authorization to load MOx fuel assemblies in Doel 3 and Tihange 2.

Load and operate PWR power plants with MOx fuel assemblies is not really a technical concern : the long international experience shows it is perfectly safe and economic. The safety and licensing process has confirmed that MOx fuel loading had negligible impact on plant safety and operation.

The experience feedback gained so far shows that there are no practical differences for a Utility to load MOX fuel instead of uranium fuel, on the plant operation point of view. In Belgium, MOX fuel assemblies are loaded together with uranium fuel assemblies supplied by other fuel vendors, letting even the Utility to make the economical and technical choice for supply of uranium fuel independently from MOX fuel. 
A Utility's experience : licensing \& use of MOX Fuel

Page 9

TABLE I

Belgian nuclear POWer Plants

\begin{tabular}{|l|l|l|l|c|c|c|}
\hline Unit & NSSS Supplier & Type & $\begin{array}{c}\text { Thermal } \\
\text { Power }\end{array}$ & $\begin{array}{c}\text { Net } \\
\text { Electrical } \\
\text { Power }\end{array}$ & Fuel & $\begin{array}{c}\text { First } \\
\text { start-up }\end{array}$ \\
\hline Doel 1 & Westinghouse & PWR 2 loops & $1192 \mathrm{MWth}$ & $392 \mathrm{MWe}$ & $14 \times 14,8 \mathrm{ft}$ & 1974 \\
\hline Doel 2 & Westinghouse & PWR 2 loops & $1192 \mathrm{MWth}$ & $392 \mathrm{MWe}$ & $14 \times 14,8 \mathrm{ft}$ & 1975 \\
\hline Tihange 1 & Framatome & PWR 3 loops & $2875 \mathrm{MWth}$ & $960 \mathrm{MWe}$ & $15 \times 15,12 \mathrm{ft}$ & 1975 \\
\hline Doel 3 & Framatome & PWR 3 loops & $3053 \mathrm{MWth}$ & $1000 \mathrm{MWe}$ & $17 \times 17,12 \mathrm{ft}$ & 1982 \\
\hline Tihange 2 & Framatome & PWR 3 loops & $2895 \mathrm{MWth}$ & $960 \mathrm{MWe}$ & $17 \times 17,12 \mathrm{ft}$ & 1982 \\
\hline Doel 4 & Westinghouse & PWR 3 loops & $3000 \mathrm{MWth}$ & $1000 \mathrm{MWe}$ & $17 \times 17,14 \mathrm{ft}$ & 1985 \\
\hline Tihange 3 & Westinghouse & PWR 3 loops & $3000 \mathrm{MWth}$ & $1015 \mathrm{MWe}$ & $17 \times 17,14 \mathrm{ft}$ & 1985 \\
\hline
\end{tabular}


TABLE ||

CORE DESIGN PARAMETERS OF TIHANGE $2 \&$ DOEL 3

\begin{tabular}{|c|c|c|c|}
\hline - Parameter & Initial & TIHANGE 2 & DOEL 3 \\
\hline$=-\cdots$ & SAR & UPRATED & UPRATED \\
\hline Core nominal power (MWth) & 2775 & 2895 & 3053 \\
\hline Core height (ft) & 12 & 12 & 12 \\
\hline Number of fuel assemblies & 157 & 157 & 157 \\
\hline Average linear heat generation rate $(\mathrm{W} / \mathrm{cm})$ & 178.5 & 186.2 & 196.4 \\
\hline Maximum radial peaking factor & 1.435 & 1.52 & 1.5 \\
\hline Maximum Fq peaking factor & 2.13 & 2.3 & 2.3 \\
\hline Cycle length (months) & 12 & 15 & 12 \\
\hline Cycle length (EFPD) & 285 & 425 & 320 \\
\hline Reloading strategy & $1 / 3$ core & $1 / 3$ core & $1 / 4$ core \\
\hline Loading pattern type & Out-In & Low leakage & Low leakage \\
\hline $\begin{array}{ll}\text { Reload size } & - \text { Total } \\
& - \text { Uranium fuel } \\
& - \text { Mox fuel }\end{array}$ & $\begin{array}{l}52 \\
52\end{array}$ & $\begin{array}{l}52 \\
44 / 40 / 40 \\
8 / 12 / 12\end{array}$ & $\begin{array}{l}44 \\
36 \\
8\end{array}$ \\
\hline Mox fuel reloading strategy & & In-In-Out & In-In-Out-Out \\
\hline Uranium fuel enrichment (\% U5) & 3.25 & 4.25 & 4.05 \\
\hline Mox fuel enrichment (\% U5 equivalent) & & 3.8 & 3.8 \\
\hline Burnable absorbers & None & Gd rods $(8 w \%)$ & None \\
\hline Number of burnable absorber rods & & 224 & \\
\hline \multicolumn{4}{|l|}{ Batch avcrage discharge Burnup (Gwd/hM) } \\
\hline - Global & 33 & 51 & 48 \\
\hline - Uranium Fuel & 33 & 52 & 49 \\
\hline - Mox fuel & & 47 & 45 \\
\hline Max assembly discharge Burnup (GWd/tHM) & 35 & 55 & 55 \\
\hline
\end{tabular}


TABLE III - LCENSING SCHEDULE

\begin{tabular}{|c|c|}
\hline Period & Activity \\
\hline Dec. 1989 & $\begin{array}{l}\text { Decision to proceed with the feasibility study and information of the Special } \\
\text { Commission by the Utility of his intend to load Mox fuel }\end{array}$ \\
\hline Feb. 1990 & $\begin{array}{l}\text { Special Commission agrees on the principles of Mox fuel loading but requests a full } \\
\text { licensing process }\end{array}$ \\
\hline $1990-1992$ & $\begin{array}{l}\text { Performance of the safety review of the impact of Mox fuel loading, including fuel and } \\
\text { core design and safety analyses }\end{array}$ \\
\hline 1991 & $\begin{array}{l}\text { Decision on the political level of a public review on the backend issues (use of Mox fuel } \\
\text { and management of the spent fuel) }\end{array}$ \\
\hline May 1992 & $\begin{array}{l}\text { Official application by the Utility for a license to load Mox fuel in Doel } 3 \text { and } \\
\text { Tihange } 2\end{array}$ \\
\hline 1991-1993 & $\begin{array}{l}\text { Technical review by the Advisory Body. The final report to the Special Commission is } \\
\text { issued in March } 1993\end{array}$ \\
\hline May 1993 & Positive advise of the Special Commission to the relevant ministries \\
\hline 1992-1994 & Public review by the Government and the Parliament on the backend issues \\
\hline June 1994 & Royal Decree of Authorisation of Mox fuel loading in Doel 3 and Tihange 2. \\
\hline 1994-1995 & $\begin{array}{l}\text { Fuel and core design and FSAR update (according to the Mox feasibility studies results } \\
\text { and to the actual plant uprating performed in Doel } 3 \text { and Tihange 2) and on site } \\
\text { implementation }\end{array}$ \\
\hline March 1995 & $\begin{array}{l}\text { First Mox loading in Tihange } 2: \text { FSAR and Tech. specs are finalised prior to start-up } \\
\text { of the plant }\end{array}$ \\
\hline June 1995 & $\begin{array}{l}\text { First Mox loading in Doel } 3: \text { FSAR and Tech. specs are finalised prior for the start-up } \\
\text { of the plant }\end{array}$ \\
\hline
\end{tabular}

TABLE IN - EQUINALENT DOSE RATES FOR MOX FUEL ASSEMBLES

\begin{tabular}{|l|l|l|}
\hline \multirow{2}{*}{ Position } & \multicolumn{1}{|c|}{ Neutrons $(\mu \mathrm{Sv} / \mathrm{h})$} & Gamma $(\mu \mathrm{Sv} / \mathrm{h})$ \\
\hline Contact & 1466 & 1238 \\
\hline $0.5 \mathrm{~m}$ & 204 & 126 \\
\hline $1.0 \mathrm{~m}$ & 94 & 58 \\
\hline $2.0 \mathrm{~m}$ & 34 & 24 \\
\hline
\end{tabular}


A Utility's experience : licensing 85 use of MOX Fuel

FIG. 1 - MOX FUEL ASSEMBLY DESIGN

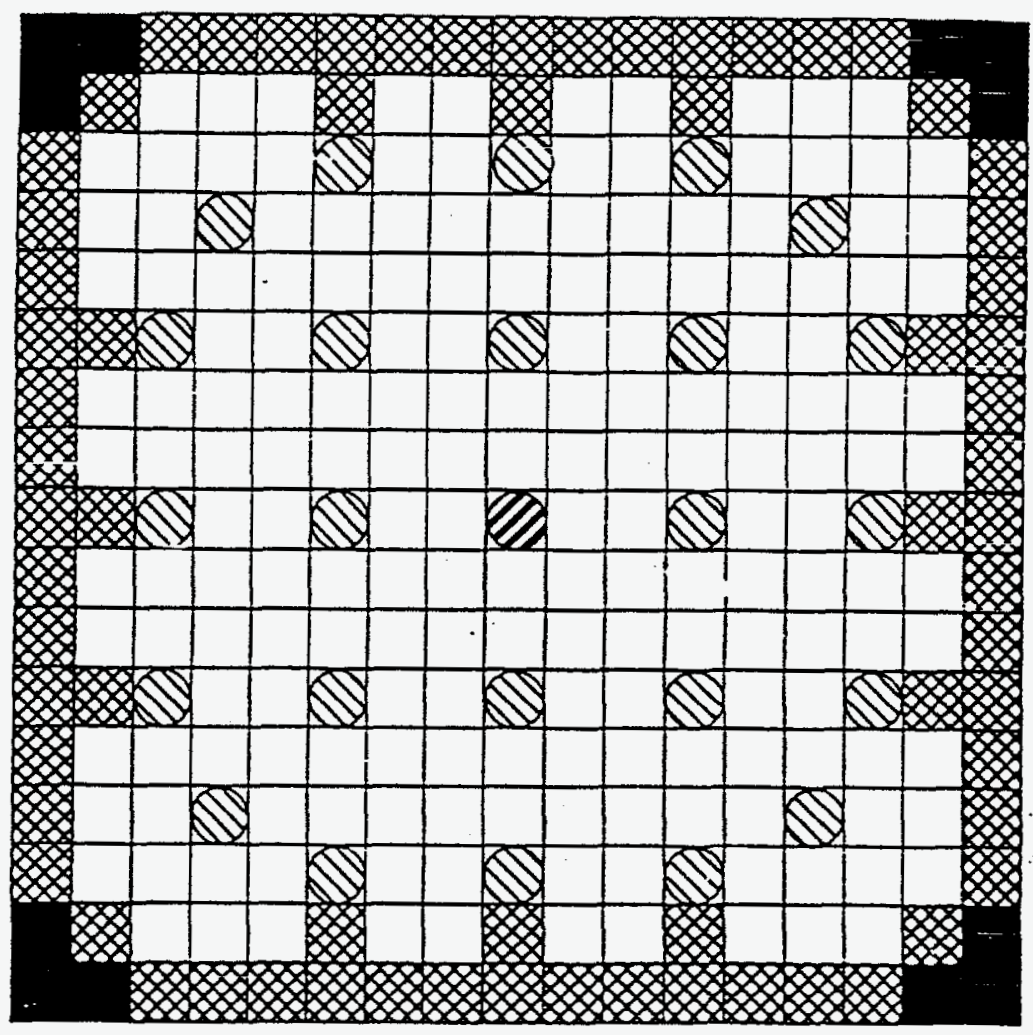

Instrumentation tube

Guide-tube

Zone 1 / Low Pu total / 12 rods

Zone 2 / Medium Pu total / 68 rods

$\square$ Zone 3 / High Pu total / 184 rods 
A Utility's experience : licensing 8s use of MOX Fuel

Page 13

\section{FIG. 2 - TIHANGE 2 - EQUIUIBRIUM CYCLE WITH MOX FUEL}

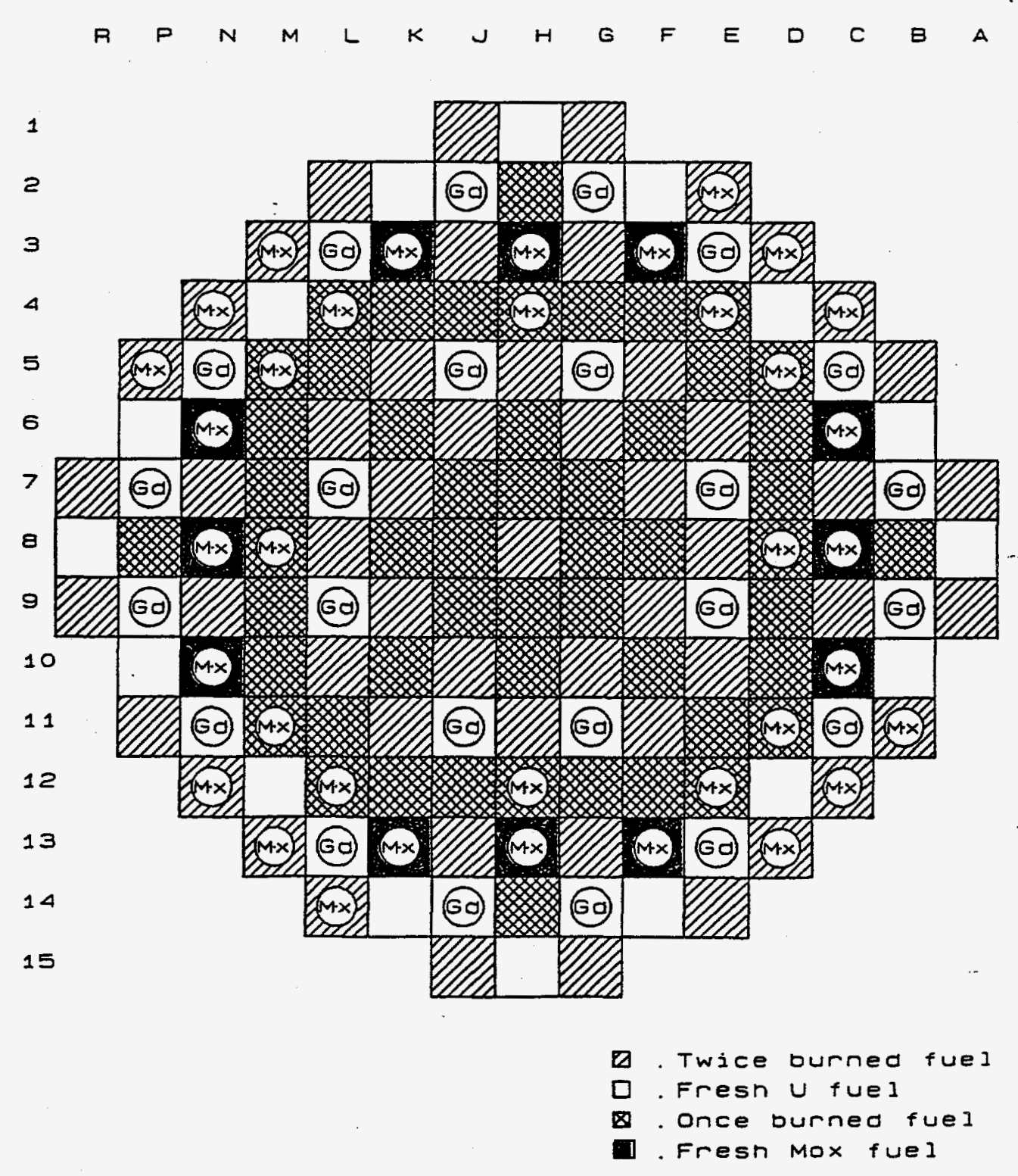




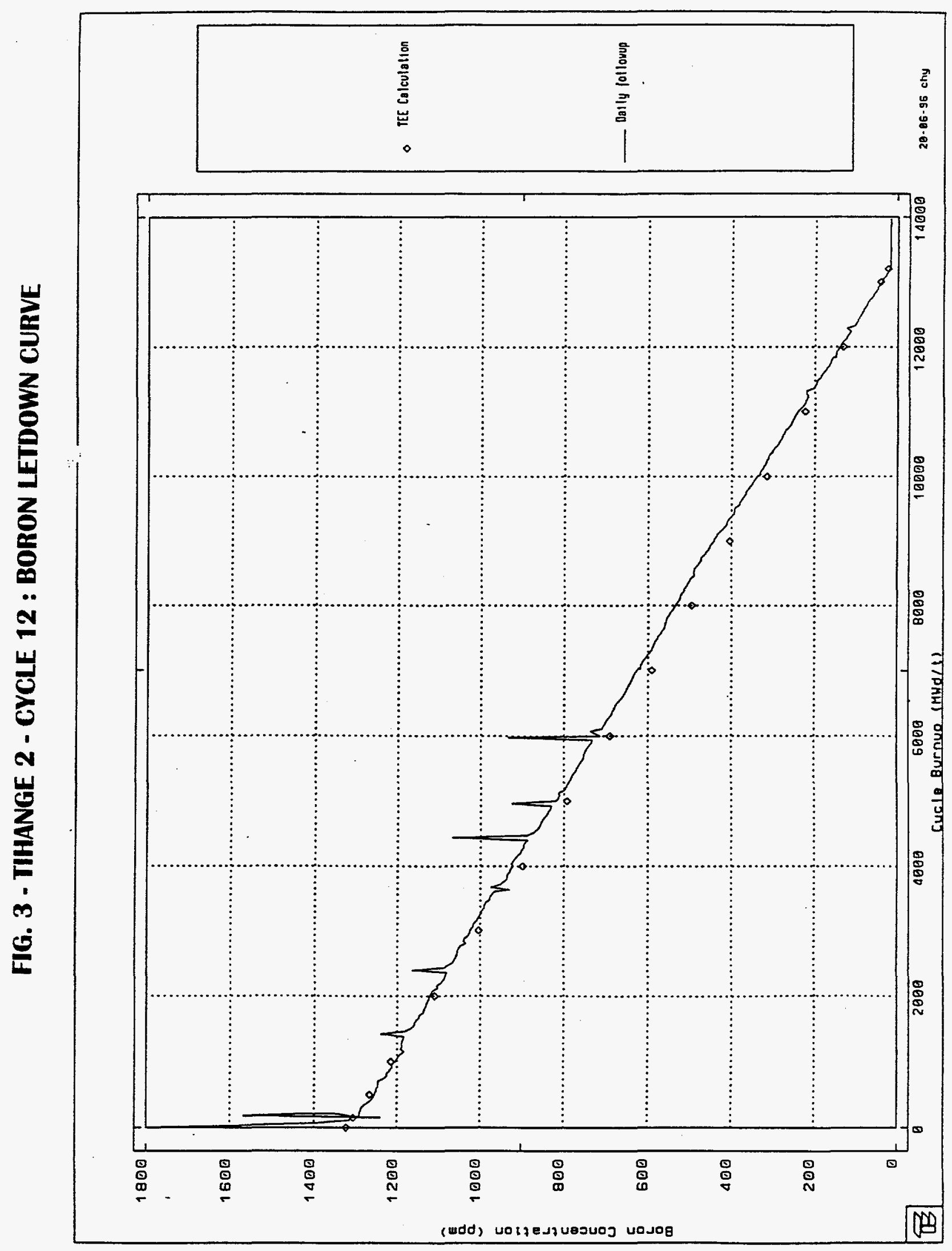

